\title{
Endohelminth communities of the perch, Perca fluviatilis (Perciformes, Percidae) from Srebarna Biosphere Reserve, Bulgaria
}

\author{
S. SHUKEROVA ${ }^{1}$, D. KIRIN ${ }^{1}$, V. HANZELOVÁ ${ }^{2}$
}

\author{
${ }^{1}$ Department of Ecology and Protection of Environment, Agricultural University - Plovdiv, Mendeleev 12, 4000 \\ Plovdiv, Bulgaria, E-mail: sonyashukerova@gmail.com; ${ }^{2}$ Parasitological Institute of the Slovak Academy of Sciences, \\ Hlinkova 3, 04001 Košice, Slovakia
}

\begin{abstract}
Summary
Altogether 180 specimens of Perca fluviatilis (L.) from Srebarna Lake, North-eastern Bulgaria, were examined for helminths during spring, summer and autumn of $2005-$ 2006. Of them, $143(79.4 \%)$ perch were infected with helminths. Thirteen helminth species were found: metacercariae of Bolbophorus confusus, Diplostomum pseudospathaceum, D. spathaceum, Ichthyocotylurus pileatus, Posthodiplostomum cuticola and Tylodelphys clavata; cestode Proteocephalus percae; acantocephalans Acanthocephalus anguillae and A. lucii and nematode larvae Contracaecum microcephalum, Eustrongilides excisus, E. tubifex and Rhaphidascaris acus. The digenean T. clavata was dominant species of the perch component community. Little seasonal differences were found in the prevalence, abundance and mean infection of helminths. Eustrongilides tubifex reported from the territory of Bulgaria for the first time, represent the new geographical records and new species of Bulgarian helminth fauna.

$P$. fluviatilis was reported as a new host record for two digeneans, namely Diplostomum pseuspathaceum and Posthodiplostomum cuticola, the cestode Proteocephalus percae, the acantocephalan Acantocephalus anguillae and the nematodes Contracaecum microcephalum and E. tubifex from the territory of Bulgaria. P. fluviatilis was reported as a new host record for D. pseudospathaceum, P. cuticola, C. microcephalum and E. tubifex from Balkan peninsula.
\end{abstract}

Keywords: Helminths; helminth communities; biodiversity; Perca fluviatilis; Srebarna Biosphere Reserve; Bulgaria

\section{Introduction}

The Srebarna Lake has been declared as a biosphere reserve under the Programme on Man and the Biosphere
(UNESCO). As a site of the World Natural Heritage, it was also included in the List of Wetlands of International Importance (Ramsar Convention) and Important Bird Areas (BirdLife International). The Srebarna Biosphere Reserve is situated in North-eastern Bulgaria $\left(44^{\circ} 7^{\prime} \mathrm{N}\right.$, $27^{\circ} 5^{\prime} \mathrm{E}$ ) and it includes the Srebarna Lake (a Danubian oxbow lake) and adjacent wet grasslands and inundated forests. The Srebarna Lake is freshwater eutrophic lake connected via an artificial canal with the Danube (Michev et al., 1998; Uzunov et al., 2001; Pehlivanov et al., 2006) and characterized by a significant diversity of highly protected species, including globally threatened fish-eating birds such as Dalmatian pelican, Pelecanus crispus Bruch, 1832, Pygmy Cormorant, Phalacrocorax pygmeus (Pallas, 1773 ) and Ferruginous duck, Aythya nyroca (Güldenstädt, 1770) (Michev et al., 1998). The total number of registered invertebrate taxa in the macrosoobenthos of the Srebarna lake was estimated to be 236 (Varadinova et al., 2009, etc.). The list of fishes from Srebarna lake include twenty six species - 18 species of Cyprinidae, 4 species of Percidae, 3 of Gobitidae and by one species of Esocidae, Umbridae, Siluridae, Gobitidae, Centrarchidae and Gasterosteidae (Pehlivanov, 2000; Pehlivanov \& Pavlova, 2009). The fish fauna is composed mainly of common Danubian species with perch, Perca fluviatilis (L.) representing one of the most abundant fish species of the lake (Pehlivanov, 2000; Pehlivanov et al., 2005; Pehlivanov \& Pavlova, 2009).

Helminth parasites of fish from Srebarna Lake have never been studied in detail (Michev et al., 1998). The only ichthyoparasitological data are those by Margaritov (1959), who reported only three helminth species, among them Bolbophorus confusus (Krause, 1914) parasitizing perch. The present study on helminth parasites of perch represents a part of comprehensive investigations carried out in the Srebarna Lake during the years 2004 - 2006 with the aim 
to characterize perch helminths as an integral part of the biodiversity inventory. Since data on fish helminth communities from the Lower Danube area are scarce, the other aim of this study was to analyze the structure of helminth communities of perch from the Srebarna Lake as well.

\section{Materials and Methods}

During spring, summer and autumn of 2005 - 2006, a total of 180 perch (the body length from 103 to $305 \mathrm{~mm}$, average $154 \pm 4.5$ ) were examined for helminth parasites. Thirty host individuals were studied per season during every year and on sixty perch per season for both years (2005 and 2006, $N=60$ ). Fish were captured by local fishermen using various methods (netting, angling or electro-fishing). They were transported alive in the water from the lake to the laboratory of Field Station - Srebarna (Laboratory of Bulgarian Academy of Sciences). After fish were dissected and immediately examined. A small part of samples was either fixed in $4 \%$ formaldehyde or frozen for subsequent studies. A total number of 2,122 helminths was obtained and examined during the whole period of investigation. Helminths were separated from internal organs and tissues and also from fins, skin, gills, eyes and brain.

All parasites were identified and counted. Cestodes and trematodes were stained in iron acetocarmine, dehydrated in ethanol series with increasing concentrations, cleared in eugenol and mounted in Canada balsam (BykhovskayaPavlovskaya, 1985; Georgiev et al., 1986; Scholz \& Hanzelová, 1998). Larval developmental stages of digeneans (metacercariae) of genus Diplostomum were cleared in dimethylphthalate and mounted in Canada balsam (Niewiadomska \& Niewiadomska-Bugaj, 1995; Shigin, 1986). Nematodes and acanthocephalans were studied as temporary glycerol mounts (Bykhovskaya-Pavlovskaya, 1985; Moravec, 1994). The ecological and epidemiological

Table 1. Species diversity of helminth parasites of the perch, Perca fluviatilis, from the Srebarna Lake (p - number of parasites; P - prevalence; MA - mean abundance; MI - mean intensity)

\begin{tabular}{|c|c|c|c|c|c|c|}
\hline \multirow[t]{2}{*}{ Helminth species } & \multirow[t]{2}{*}{$\mathbf{p}$} & \multirow[t]{2}{*}{$\mathbf{P}(\%)$} & \multirow[t]{2}{*}{$\mathbf{M A} \pm \mathbf{S D}$} & \multicolumn{2}{|c|}{ Intensity } & \multirow[t]{2}{*}{ Site } \\
\hline & & & & $\mathbf{M I} \pm \mathbf{S D}$ & Range & \\
\hline \multicolumn{7}{|l|}{ Trematoda } \\
\hline Bolboforus confusus (Krause, 1914), metacercariae & 8 & 4.4 & $0.04 \pm 0.21$ & 1.00 & 1 & $\begin{array}{l}\text { mesentery, gills } \\
\quad \text { (encysted) }\end{array}$ \\
\hline $\begin{array}{l}\text { Diplostomum pseudospathaceum, (Newiadomska, } \\
\text { 1984), metacercariae }\end{array}$ & 5 & 1.1 & $0.03 \pm 0.31$ & $2.50 \pm 2.12$ & $1-4$ & lens \\
\hline $\begin{array}{l}\text { Diplostomum spathaceum (Rudolphi, 1819), } \\
\text { metacercariae }\end{array}$ & 5 & 1.7 & $0.03 \pm 0.25$ & $1.67 \pm 1.15$ & $1-3$ & lens \\
\hline $\begin{array}{l}\text { Ichthyocotylurus pileatus (Rudolphi, 1802), } \\
\text { metacercariae }\end{array}$ & 20 & 1.1 & $0.11 \pm 1.05$ & 10 & 10 & $\begin{array}{l}\text { stomach and pyloric } \\
\text { caeca }\end{array}$ \\
\hline $\begin{array}{l}\text { Posthodiplostomum cuticola (Nordmann, 1832), } \\
\text { metacercariae }\end{array}$ & 2 & 0.6 & $0.01 \pm 0.15$ & 2.00 & 2 & skin, gills \\
\hline Tylodelphys clavata (Nordmann, 1832), metacercariae & $>2000$ & 75.0 & $11.11 \pm 22.25$ & $14.81 \pm 24.61$ & $1-118$ & vitreous humour \\
\hline \multicolumn{7}{|l|}{ Cestoda } \\
\hline Proteocephalus percae (Müller, 1780) & 9 & 1.7 & $0.05 \pm 0.39$ & 3.00 & 3 & stomach, intestine \\
\hline \multicolumn{7}{|l|}{ Acanthocephala } \\
\hline Acanthocephalus anguillae (Müller, 1776) & 1 & 0.6 & $0.01 \pm 0,07$ & 1.00 & 1 & intestine \\
\hline Acanthocephalus lucii (Müller, 1776) & 1 & 0.6 & $0.01 \pm 0.07$ & 1.00 & 1 & intestine \\
\hline \multicolumn{7}{|l|}{ Nematoda } \\
\hline $\begin{array}{l}\text { Contracaecum microcephalum (Rudolphi, 1809), } \\
\text { larvae }\end{array}$ & 2 & 1.1 & $0.01 \pm 0.11$ & 1.00 & 1 & intestine \\
\hline Eustrongilides excisus Jägerskiöld, 1909, larvae & 44 & 13.9 & $0.24 \pm 0.88$ & $1.76 \pm 1.74$ & $1-9$ & $\begin{array}{l}\text { mesentery, skin, } \\
\text { muscles, surface of } \\
\text { internal organs, } \\
\text { (encysted) }\end{array}$ \\
\hline Eustrongilides tubifex (Nitzsch, 1819), larvae & 1 & 0.6 & $0.01 \pm 0.07$ & 1.00 & 1 & $\begin{array}{l}\text { mesentery } \\
\text { (encysted) }\end{array}$ \\
\hline Rhaphidascaris acus (Bloch, 1799), larvae & 24 & 3.3 & $0.13 \pm 0.77$ & $4.00 \pm 1.55$ & $2-5$ & $\begin{array}{l}\text { intestine, abdominal } \\
\text { cavity }\end{array}$ \\
\hline
\end{tabular}


terminology followed Bush et al. (1997). Brillouin's Diversity Index and Berger-Parker Dominance Index were calculated as described by Maguran (1988). The dominance was determined according to the criteria proposed by Kennedy (1993) on the basis of the prevalence $(\mathrm{P})$ : satellite species $(\mathrm{P}<10)$, secondary species $(10<\mathrm{P}<20)$ and core species $(\mathrm{P}>20)$. Mean abundance (MA) and mean intensity of infection (MI) were calculated using Microsoft Excel and STATISTICA 6.0 program. Seasonal differences were evaluated by applying Chi-square test for prevalence, Bootstrap 2-sample t-test for mean intensity of infection (Quantitative Parasitology - version 3.0 available at website http://www.behav.org/qp/qp.htm; Rozsa et al., 2000) and Kruskal-Wallis test $H$ for the abundance (STATISTICA 6.0).

The species of parasites were deteminated by Bykhovskaya-Pavlovskaya, 1982; Scholz \& Hanzelová, 1998; Shigin, 1986; Moravec, 1994).

\section{Results}

Species diversity of helminthes

Thirteen endohelminth species were identified: 6 digeneans - Bolboforus confusus, Diplostomum spathaceum, D. pseudospathaceum, Ichthyocotylurus pileatus, Posthodiplostomum cuticola and Tylodelphys clavata; 1 cestode species - Proteocephalus percae; 2 acantocephalans Acanthocephalus anguillae and A. lucii and 4 nematodes Contracaecum microcephalum, Eustrongilides excisus, E. tubifex and Raphidascaris acus. No monogeneans were found. Three species, the tapeworm $P$. percae and both acanthocephalans $(23.1 \%)$ occurred as adults and remaining 10 species $(76.9 \%)$ were found at the developmental stage of the larvae (Table 1). P. percae, A. lucii, A. anguillae and $R$. acus) were autogenic species and allogenic species group comprised of other nine helminth species parasitizing fish-eating birds at their mature stage.

Table 2. Seasonal variation of helminth infection indices in perch from the Srebarna Lake (P - prevalence; MI - mean intensity, $\mathrm{N}$-number of examined host)

\begin{tabular}{|c|c|c|c|c|c|c|}
\hline \multirow[t]{2}{*}{ Helminth species } & \multicolumn{2}{|c|}{ Spring $(\mathrm{N}=60)$} & \multicolumn{2}{|c|}{ Summer $(N=60)$} & \multicolumn{2}{|c|}{ Autumn $(\mathrm{N}=60)$} \\
\hline & $\begin{array}{c}P \\
(\%)\end{array}$ & $\begin{array}{c}\mathrm{MI} \pm \mathrm{SD} \\
\text { Range }\end{array}$ & $\begin{array}{c}\mathbf{P} \\
(\mathbf{\%})\end{array}$ & $\begin{array}{c}\mathrm{MI} \pm \mathrm{SD} \\
\text { Range }\end{array}$ & $\begin{array}{c}P \\
(\%)\end{array}$ & $\begin{array}{c}\mathrm{MI} \pm \mathrm{SD} \\
\text { Range }\end{array}$ \\
\hline \multirow[t]{2}{*}{ Bolboforus confusus } & 3.3 & 1.00 & 10.0 & $0.83 \pm 0.41$ & 1.7 & 1.00 \\
\hline & & 1 & & 1 & & 1 \\
\hline \multirow[t]{2}{*}{ Diplostomum pseudospathaceum } & & & & & 3.3 & $2.50 \pm 2.12$ \\
\hline & & & & & & $1-4$ \\
\hline \multirow[t]{2}{*}{ Diplostomum spathaceum } & 3.3 & 1.00 & 1.7 & 3.00 & & \\
\hline & & 1 & & 3 & & \\
\hline \multirow[t]{2}{*}{ Ichthyocotylurus pileatus } & & & 3.3 & 10 & & \\
\hline & & & & 10 & & \\
\hline \multirow[t]{2}{*}{ Posthodiplostomum cuticola } & & & 1.7 & 2.00 & & \\
\hline & & & & 2 & & \\
\hline \multirow[t]{2}{*}{ Tylodelphys clavata } & 56.7 & $15.29 \pm 25.78$ & 81.7 & $8.51 \pm 10.20$ & 86.7 & $20.44 \pm 31.51$ \\
\hline & & $1-109$ & & $1-44$ & & $1-118$ \\
\hline \multirow[t]{2}{*}{ Proteocephalus percae } & 1.7 & 3.00 & & & 3.3 & 3.00 \\
\hline & & 3 & & & & 3 \\
\hline \multirow[t]{2}{*}{ Acanthocephalus anguillae } & 1.7 & 1.00 & & & & \\
\hline & & 1 & & & & \\
\hline \multirow[t]{2}{*}{ Acanthocephalus lucii } & 1.7 & 1.00 & & & & \\
\hline & & 1 & & & & \\
\hline \multirow[t]{2}{*}{ Contracaecum microcephalum } & & & & - & 3.3 & 1.00 \\
\hline & & & & & & 1 \\
\hline \multirow[t]{2}{*}{ Eustrongilides excisus } & 8.3 & $1.40 \pm 0.55$ & 10.0 & $2.50 \pm 3.21$ & 23.3 & $1.57 \pm 1.09$ \\
\hline & & $1-2$ & & $1-9$ & & $1-4$ \\
\hline \multirow[t]{2}{*}{ Eustrongilides tubifex } & & & & & 1.7 & 1.00 \\
\hline & & & & & & 1 \\
\hline \multirow[t]{2}{*}{ Rhaphidascaris acus } & & & 10.0 & $4.00 \pm 1.55$ & & \\
\hline & & & & $2-5$ & & \\
\hline
\end{tabular}




\section{Component community}

Helminths were found in $143(79.44 \%)$ of 180 fish hosts examined during two years. The metacercariae of $T$. clavata showed the highest epidemiological indices $(\mathrm{P}=$ $75.0 \% ; \mathrm{MA}=11.1 ; \mathrm{MI}=14.8$ ) over the entire period of our study. This species also represented the only core species parasitizing perch in the Srebarna Lake. On the other hand, the lowest parameters of infestation were found in $P$. cuticola, A. anguillae, A. lucii and E. tubifex (Table 1). E. excisus, with the prevalence ranging seasonally (between $8.3-23.3 \%$ ) was the secondary species and all other helminths were ranked among satellite parasites of perch (Table 1 and 2).

Significant seasonal differences in the prevalence of perch helminths were recorded in metacercariae of T. clavata and nematode larvae of E. excisus (Chi-square test, $\mathrm{df}=2, \mathrm{p}<$ $0.05)$. Both species occurred less frequently in spring in comparison with summer and autumn seasons. Variation of the mean abundance of perch helminths was slightly more expressive. Besides former two species, significant differences among three seasons were evidenced also in $R$. acus nematode larvae (Kruskal-Wallis test: T. clavata - H $(2, \mathrm{~N}$ $=180)=16.02137, \mathrm{p}=0.0003 ;$ E. excisus $-\mathrm{H}(2, \mathrm{~N}=180)$ $=12.34168 \mathrm{p}=0.0021 ;$ R. acus $-\mathrm{H}(2, \mathrm{~N}=180)=6.582291$ $\mathrm{p}=0.0372$ ). Seasonal changes in mean intensity of infection were found being negligible. More prominent differences were observed only in mean intensity of infection of $T$. clavata between summer and autumn (Bootstrap t-test $\mathrm{p}$ $<0.05$ ) (Table 2). The species diversity and dominance were alike in the different season periods (Table 3 ). lake reported only 3 helminth species. In our study, 13 helminth species have been identified and all but one $(B$. confusus) are recorded for the first time from perch in the Srebarna Lake.

To date, helminth parasites of perch have been studied from various rivers and water reservoirs in Bulgaria. In Bulgarian part of the Danube River, Margaritov (1966) found only three helmiths parasitic in perch, namely Acanthocephalus lucii, the digenean Nicolla skrjabini (Iwanitzky, 1928) and Rhabdochona sp. nematodes. Kakacheva-Avramova (1977) and Kakacheva-Avramova et al. (1978) discovered more varied diversity of perch parasites from the Danube River.

They found digeneans Bunodera luciupercae (Müller, 1776), Diplostomum baeri Dubois, 1937 (metacercariae), N. skrjabini, acanthocephalans A. lucii and Pomphorhynchus laevis (Müller, 1776) and also specimens of Rhabdochona and Contracaecum (larvae).

More recent papers dealing with perch parasites by Nedeva \& Grupcheva (1996), Nedeva \& Babacheva (1999), Nedeva et al. (2003) and Kirin (2005) described the occurrence of some other helminths of perch from Bulgarian rivers and water reservoirs. Except from previously mentioned species, they gave an account of findings of two monogeneans Gyrodactylus gasterostei Glaser, 1974 and Dactylogyrus anchoratus (Dujardin, 1845), digeneans Diplostomum chromatophorum (reported as D. volvens), Ichthyocotylurus pileatus and Tylodelphys clavata, a cestode Caryophyllaeus brachycollis Janiszweska, 1953, acanthocephalans Acanthocephalus anguillae and Neoechinorhin-

Table 3. Seasonal variations of species diversity and dominance within helminth communities in the perch from the Srebarna Lake

\begin{tabular}{lcccc}
\hline Season & $\begin{array}{c}\text { Number of helminth } \\
\text { species }\end{array}$ & $\begin{array}{c}\text { Number of helminth } \\
\text { individuals }\end{array}$ & $\begin{array}{c}\text { Brillouin's Diversity } \\
\text { Index }\end{array}$ & $\begin{array}{c}\text { Berger-Parker Dominance } \\
\text { Index }\end{array}$ \\
\hline Spring & 7 & 536 & 0.165 & 0.970 \\
Summer & 7 & 486 & 0.596 & 0.858 \\
Autumn & 7 & 1100 & 0.185 & 0.965 \\
\hline
\end{tabular}

\section{Infracommunity}

Out of 180 examined fish hosts, 143 specimens $(79.4 \%)$ were infected with helminths. The infracommunities consisted of $1-3$ helminth species (mean value 1.3 ); 102 hosts $(71.3 \%)$ were infected with only one helminth species, 33 perch $(26.6 \%)$ with two species and 8 perch $(5.6$ $\%)$ with 3 helminth species. The maximum number of helminth individuals recorded in a single perch was 122 (in two fish). Perch were mostly infected with one and five helminths (17.0\% and $9.4 \%$, respectively). Fifteen $(8.3$ $\%)$ fishes harboured two helminths and 14 (7.8\%) perch hosted 4 worms. The total number of helminths ranged from 1 to 122 specimens per one fish (11.8 on average).

\section{Discussion}

Last 50 years, the helminth fauna of perch was not subjected to serious complex research in the Srebarna Lake. Margaritov (1959), within his study of fish fauna of this chus rutili (Müller, 1870) and nematodes Eustrongilides excisus and Raphidascaris acus.

The present findings of Eustrongilides tubifex is reported for territory of Bulgaria for the first time and thus represent the new geographical records and new species of Bulgarian helminth fauna. Diplostomum pseudospathaceum, Posthodiplostomum cuticola, the cestode Proteocephalus percae, the acantocephalan Acantocephalus anguillae and the nematodes Contracaecum microcephalum and E. tubifex are reported from the first time for the helminth communities of $P$. fluviatilis from the territory of Bulgaria. $P$. fluviatilis was reported as a new host record for $D$. pseudospathaceum, P. cuticola, C. microcephalum and E. tubifex from Balkan peninsula.

Srebarna Lake is an oxbow lake, last 15 years connected with the Danube via an artificial canal. Since fish populations in the lake and the river are believed to be closely associated (frequently exchanging individuals), the species composition of the component communities of perch were 
expected to be very much alike. However, there was only one species, the acanthocephalan $A$. lucii which was found parasitic in perch in both the Danube River and the Srebarna Lake.

A possible reason of this phenomenon could be the different ecological conditions of these localities. The parasite species with complex life cycles which were mostly recorded in the Danube River use benthic molluscs and crustaceans as intermediate hosts. The Srebarna Lake bottom is covered by a thick layer of detritus which is generally associated with low oxygen concentrations and low density of benthic organisms. As a result of this, the composition of the benthic communities involve mostly dipterans (chironomids) of the Srebarna Lake (Uzunov et al., 2001). Molluscs are almost entirely lacking in benthic samples from the central part of the lake which is probably due to the thick detritus layer and the absence of aquatic vegetation (Angelov, 2000; Uzunov et al., 2001). One of the most abundant mollusc species, Radix ovata (L.) serves as the intermediate host of $T$. clavata, representing the only core species parasitizing perch in the Srebarna Lake. The great number of metacercariae of Diplostomum recorded in the course of the present study can be explained with the large diversity of fish-eating birds (Michev et al., 1998; Angelov, 2000) and rather high abundance of snails occurring in the shore region of the lake.

Halmetoja et al. (2000) who studied parasites of perch from a Vetämäjärvi natural lake in Finland recorded 18 parasite species. Nine core species with the prevalence exceeded $20 \%$ were recorded: Bunodera luciopercae (48.6 \%), Diplosthomum spp. (97.3\%), Diplosthomum spathaceum (48.6\%), T. clavata (metacercariae; $75.5 \%$ ), Ichthyocotylurus variegtus (43.2\%), Trieanophorus nodulosus $(29.7 \%)$, P. percae $(21.6 \%)$, Camallanus lacustris (91.9\%) and Acanthocephalus lucii (62.2\%). Concerning seasonal dynamics, the prevalence of core species was the highest in autumn and the lowest in spring (Halmetoja et al., 2000), which correlates well with results of Nedeva \& Grupcheva (1996) also with present results.

Based on several most recent parasitological studies (Halmetoja et al., 2000; Kirin, 2005; Sobecka \& Slomińska, 2007; Morozińska-Gogol, 2009; present study), the helminth species diversity is not very high in perch $(13-42)$ and digeneans always represent a dominant group of its component communities which was also found during our studies in the Srebarna Lake.

\section{Acknowledgments}

We are grateful to Prof. B.B. Georgiev and Dr. A. K. Kostadinova (Central Laboratory of General Ecology, Bulgarian Academy of Sciences, Sofia, Bulgaria) for valuable suggestions to the present study and help in statistical analyses. This study was also supported by the Grant Agency VEGA (project No. 2/7192/27).

\section{References}

ANGELOV, A. (2000): Freshwater molluscs (Mollusca: Gastropoda and Bivalvia) from the Srebarna Lake, Northeastern Bulgaria. Hist. Natur. Bulg., 11: 133 - 139

Bush, A. O., Lafferty, K. D., Lotz, J. M., Shostak, A. W. (1997): Parasitology meets ecology on its own terms: Margolis et al. revisited. J. Parasitol., 83: 575 - 583

Bykhovskaya-Pavlovskaya, I. E., Gusev, A. V., DubININA, M. N., IZJUMOVA, N. A, SMIRNOVA, T. S., SOKOLOVSKayA, I. L., Shteyn, G. A., Shulman, S. S., Epshteyn, V. M. (1962): Key to parasites of freshwater fish of USSR. 776 pp. Moscow, Izdatelstvo Akademii Nauk SSSR (In Russian).

ByKhovskaya-Pavlovskaya, I. E. (1985): Parasites of fish. Manual on study. Nauka, Leningrad (In Russian)

Georgiev, B., Biserkov, V., Genov, T. (1986): In toto staining method for cestodes with iron acetocarmine. Helminthologia, 23: 279 - 281

Halmetoja, A., Valtonen, E., Koskenniemi, E. (2000): Perch (Perca fluviatilis L.) parasites reflect ecosystem conditions: a comparison of a natural lake and two acidic reservoirs in Finland. Int. J. Parasitol., 30: 1437 - 1444

KaKACHEVA-AvramovA, D. (1977): Study on the helminth composition of fish from the Bulgarian part of the Danube River. Khelmintologiya, 3: 20 - 45 (In Bulgarian)

KaKacheva-Avramova, D., Margaritov, N., GruPtSCHEVA, G. (1978): Parasites of fish from Bulgarian Part of Danube River. In RusseV, B. AND NAIDENOW, W. (Eds): Limnology of Bulgarian sector of the Danube River. BAN, Sofia, (In Bulgarian)

KENNEDY, C. (1993): The dynamics of intestinal helminth communities in eels Anguilla anguilla in a small stream: long-term changes in richness and structure. Parasitology, 107: $71-78$

KIRIN, D. (2005): Ecological research of fishes and appraisal of the condition of the freshwater ecosystems from the Arda River. J. Env. Prot. Ecol., 6: 91 - 96

MAGURAN, A. (1988): Ecological diversity and its measurement. Princeton University Press, Princeton

MARGARITOV, N. (1959): Helminths of some freshwater fish in our country. Inst. Fish Ind., Varna, (In Bulgarian) MARGARITOV, N. (1966): Helminths of digestive system and body cavita of fishes from Bulgarian part of Danube River. Bull. Inst. Zool. Mus., 20: $157-173$

Michev, T., Georgiev, B., Petrova, A., Stoyneva, M. (1998): Biodiversity of the Srebarna Biosphere Reserve, Checklist and Biblography. Pensoft, Sofia

Moravec, F. (1994): Parasitic nematodes of freshwater fish of Europe. Academia, Prague

MOROZIŃSKA-GOGOL, L. (2009): A check list of parasites of percid fishes (Actinopterygii: Percidae) from the estua-ries of the Polish coastal zones. Helminthologia, 4: 196 - 203

NedeVA I., Grupcheva, G. (1996): Analysis of the parasite fauna of predatory fishes in the contitions of the 
Zrebchevo Reservoir. Proceedings of International symposium Ecology, Burgas, 68 - 70

Nedeva, I., Atanasov, G., Karaivanova, E., Cakis, P., LENHARDT, M. (2003): Pomphorhynchus laevis (Müller, 1776) from the river Danube. Exp. Path. Parasitol., 6: 14 - 16 NedeVA, I., BABACHEVA, T. (1999): New Bulgarian fauna species belonging to Monogenea (Van Beneden, 1858) Bychowsky, 1937. Exp. Path. Parasitol., 3: 7 - 10

Niewiadomska, K, Niewiadomska-BugaJ, M. (1995): Optimal identification procedure for Diplostomum paracaudum (Iles, 1959) and D. pseudospathaceum Niewiadomska, 1984 metacercariae (Digenea) based on morphological characters. Syst. Parasitol., 30: $165-171$

PehlivanOV, L. (2000): Ichthyofauna of the Srebarna Lake, the Danube basin: State and Significance of the Management and Conservation Strategies of this Wetland. Limn. Rep. Croatia 33: 317 - 322

Pehlivanov, L., Tzavkova, V., Vassilev, V. (2006): Development of the zooplankton community in the Srebarna Lake (north-eastern Bulgaria) along the process of ecosystem rehabilitation. Proceedings of the 36th International Conference of IAD, Vienna, 280 - 284

Pehlivanov, L., VassileV, V., VAssileV, M. (2005) Changes of ichthyofauna of Srebarna Lake during the past sixty years. In Proceedings of First National Scientific Conference of Ecology, Sofia. pp. $265-270$
Pehlivanov, L., Pavlova, M. (2009): State and succession of the ichthyofauna in the antropogenous modified environment of the Srebarna Lake (Danube floodplain, North-East Bulgaria). Scientific Annals of the Danube Delta Institute, Tulcea - Romania, 2009, 15, 35 - 40 pp RozSA, L., ReICZIGEL, J., MAJOROS, G. (2000): Quantifying parasites in samples of hosts. J. Parasitol., 86: 228 - 232 SobecKA, E., SŁomiŃsKA, M. (2007): Species richness, diversity and specificity of the parasites of bream Abramis brama (L.) and perch Perca fluviatilis L. in the estuary of the Odra River, Poland. Helminthologia, 4: 188 - 192

SHIGIN, A. (1986): Trematode fauna of the USSR. Genus Diplostomum. Metacercariae. Nauka, Moscow

Scholz T., HANZElovÁ, V. (1998): Tapeworms of the genus Proteocephalus Weinland, 1958 (Cestoda: Proteocephalidae), parasites of fishes in Europe. Academia, Praha) Uzunov, Y., Tzavkova, V., Todorov, I., VARAdinova, E. (2001): The macrozoobenthic fauna of the Biosphere reserve Srebarna Lake in North-Eastern Bulgaria. Lauterbornia, 40: 43 - 53

Varadinova E., Pehlivanov, L., Moskova, G., UZUNOV, Y. (2009): Development and actual state of the macrozoobenthic fauna in the Srebarna biosphere reserve (north-east Bulgaria). Comptes rendus de l'Acad_emie bulgare des Sciences. BIOLOGIE Hydrobiologie. $6 \overline{2}$, (2), $243-248$ 